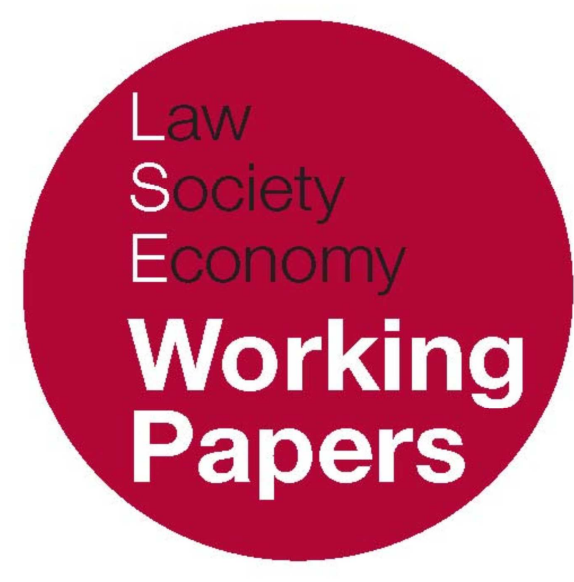

\title{
Law after Lehmans
}

\begin{abstract}
Jo Braithwaite
LSE Law, Society and Economy Working Papers 11/2014 London School of Economics and Political Science
\end{abstract}

Law Department

This paper can be downloaded without charge from LSE Law, Society and Economy Working Papers at: www.lse.ac.uk/collections/law/wps/wps.htm and the Social Sciences Research Network electronic library at: http://ssrn.com/abstract=2391148.

(C) Jo Braithwaite. Users may download and/or print one copy to facilitate their private study or for non-commercial research. Users may not engage in further distribution of this material or use it for any profit-making activities or any other form of commercial gain. 


\title{
Law after Lehmans
}

\author{
Jo Braithwaite *
}

\begin{abstract}
The September 2008 collapse of the Lehman Brothers group marked the nadir of the global financial crisis. While the regulatory aftermath has been extensively debated, the effects of the case law that arose from the insolvency have not. This paper explains the need to redress the balance. It starts by considering the quantity and qualities of the Lehmans case law, examining why the 30 plus decisions handed down by the English courts enjoy an unusually high precedent-setting potential. The paper proceeds by analysing the precedential effects of these decisions, and it reports on a recent workshop held at the London School of Economics that met to consider this question. Subject to the event's terms of engagement, the paper draws out several themes from the discussion, including the impact of the Lehmans cases on the principles of contractual interpretation, the law of trusts and insolvency law. By way of conclusion, it is submitted that the impact of Lehmans case law reaches far beyond that particular insolvency, to worldwide users of standard form documents, the global financial markets and the common law itself. Seen in this light, the Lehmans case law is a significant, but under-appreciated, side-effect of the global financial crisis.
\end{abstract}

\footnotetext{
* Department of Law, London School of Economics. The author gratefully acknowledges Elena Zaccaria's valuable assistance with part 2 of the paper. Any errors are the author's own. The author is also grateful for the financial support provided by the LSE Law and Financial Markets Project for the Law after Lehmans' event, discussed in part 2 of the paper. This event took place at the LSE on 10 October 2013, subject to the Chatham House Rule. As a result this note discusses certain general themes that emerged from the discussion, but does not identify speakers or participants. The account of the event is solely the author's own.
} 


\section{INTRODUCTION}

At 6.56am London time on 15 September 2008, Lehman Brothers Holdings Inc. ('LBHI') became the biggest bankruptcy in US history. ${ }^{1}$ LBHI was the ultimate parent company of the Lehman Brothers group, with some 2,000 subsidiaries worldwide. ${ }^{2}$ Around 80 of these subsidiaries entered into insolvency proceedings in 18 different jurisdictions shortly after LBHI. ${ }^{3}$ Related litigation started in the English courts almost immediately, with the earliest reported decisions including Mr Justice Morgan's refusal of RAB Capital's urgent application seeking the return of its assets from its Lehman prime broker. ${ }^{4}$ Since then, the litigation arising out of the Lehman Brothers' insolvency has continued apace. As regards the English courts, there have been at least 33 decisions to date, eight of which have been handed down by the Court of Appeal, and three by the Supreme Court. ${ }^{5}$

This paper considers the importance and impact of this set of cases, and it is organised in two main parts. The first draws upon the full set of Lehmans decisions handed down by the English courts since September 2008, in order to assess its precedent-setting potential. The discussion looks into the group's organisation and the nature of the contracts underpinning disputed transactions as a way of explaining the quantity and qualities of these decisions. This part of the paper concludes that the Lehmans cases have an unusually high capacity to change the legal rules affecting a broad sweep of stakeholders. The following part of the paper starts to evaluate some of these precedential effects. The discussion proceeds by drawing out some of the findings of a recent conference, 'Law after Lehmans', which was held at the London School of Economics in October 2013. The analysis is organised around contract, trusts and insolvency law. It considers examples where Lehmans cases have had an impact by way of precedent, and also where these decisions which have triggered new legislation. The paper concludes that the Lehmans insolvency has already had a marked effect by way of the courts, and this side-effect of the global financial crisis deserves much closer scrutiny from regulators and academics alike.

\footnotetext{
${ }^{1}$ In evidence given to the Financial Crisis Inquiry Commission, LBHI's lawyer, Harvey Miller of Weil, Gotshall \& Manches LLP, described this as the 'largest, most complex, multi-faceted and far-reaching bankruptcy case ever filed in the United States'. Evidence quoted in Financial Crisis Inquiry Report: Final Report of the National Commission on the Causes of the Financial and Economic Crisis in the United States (PublicAffairs: 2011) 340. (Hereafter, the 'FCIR').

${ }^{2}$ Re Lehman Brothers International (Europe) [2009] EWHC 3228 (Ch) (hereafter, 'CASS7 first instance') [44] and [49], reproducing the parties' Statement of Assumed Facts.

${ }^{3}$ FCIR, n 1 above, 340. LBIE entered into administration on 7.56am on the same day. See discussion in text accompanying $\mathrm{n} 20$ below.

${ }^{4}$ RAB Capital v Lehman Brothers International (Europe) [2008] EWHC 2335 (Ch).

5 The term 'decisions' rather than 'cases' is used in order to capture multiple decisions in the same case, i.e., 'decisions' includes rulings on applications (e.g., for summary judgment) as well as judgments after trial and appeals. The details of these decisions are set out in various forms in the two Appendices to this article.
} 


\section{PRECEDENT-SETTING POTENTIAL}

Why does the Lehmans litigation matter? In terms of history, the cases that continue to flow out of the collapse of the fourth largest investment bank in the US $^{6}$ deserve attention as part of a full account of what the Chairman of the Federal Reserve (and distinguished economic historian) Ben Bernanke called this 'calamity'. ' As 2008's many analogies with the Great Depression showed, policymakers can draw valuable lessons from rigorous historical accounts. However, in terms of law, the cases are important for a more pressing reason, namely, their capacity to apply, and thereby develop, legal rules. Thus, when the courts adjudicate questions arising from events like the collapse of Lehmans, they create a feedback loop between law and the crisis.

While every case may enjoy the potential to set precedent, this part of the paper explains why the Lehmans cases are particularly likely to do so. Most obviously, this is because of the high volume of Lehman-related decisions handed down by the English courts over the last five years. The effects of this spike of cases are particularly significant in an area of law where relatively few cases reach appellate level and, at the same time, the rules remain overwhelmingly 'judgemade'. 8 In addition, however, these decisions are unusually comprehensive, concerned with highly standardised subject-matter, typically focused on the law rather than facts, and, in some instances, the result of relatively rare procedural steps that are designed to produce judgments of broad applicability. Therefore, it is not only the quantity, but also the qualities of the Lehman cases, that explain their extensive impact on the law. These qualities may be explained by two underlying factors in play in the Lehman Brothers group's insolvency, which are considered further below.

\section{THE GROUP’S ORGANISATION}

The first factor that helps to explain the precedent-setting capacity of the English courts' decisions arising from the collapse of Lehmans is the organisation of the group's businesses. As described in some detail in several of the reported cases, including particularly the pensions litigation, the Lehman Brothers group was organised by reference to products rather than by company or by jurisdiction. ${ }^{9}$ As it was put in one decision

\footnotetext{
${ }^{6}$ Belmont Park Investments Pty Ltd v BNY Corporate Trustee Services Ltd [2011] UKSC 38, [18].

7 Evidence of Federal Reserve Chairman Ben Bernanke to the Federal Crisis Inquiry Commission, reproduced at FCIR n 1 above, 339. Ben Bernanke was an academic specialising in the Great Depression before his government career. He expressly drew on this historical perspective in the midst of managing the recent crisis. See, for e.g., B Bernanke, Essays on the Great Depression (Princeton University Press: 2004). ${ }^{8}$ R Goode, Commercial Law in the next Millennium (Sweet \& Maxwell: 1998) 15.

${ }_{9}$ The group's organisation was particularly significant, and therefore scrutinised at length, in the Lehmans pensions litigation, part of which considered whether a 'Financial Support Direction' should be imposed on Lehman entities including LBHI, LBEL and LBIE for the benefit of the pension scheme run on behalf of 4,400 employees by their employer, a Lehmans operating company LBL. For e.g., see Lehman Brothers Pension Scheme [2010] Pens LR 445 [22]-[36].
} 
[...] the group operated on global business/ product lines, which cut across the legal entity structure, with the top management in New York, supported by regional headquarters in London and Tokyo. ${ }^{10}$

Later on, the same judgment, citing the administrators' evidence, described how the group was 'organised in functional and market areas, rather than by legal entity' and on a day to day basis it was 'managed and run mainly along global product lines, rather than as separate entities'. ${ }^{11}$ This turned out to be very significant for London. The group's European hub, Lehman Brothers International (Europe) Ltd ('LBIE'), was based here, and, thanks to this feature of the group's organisation, it became involved in a vast array of different businesses. LBIE's 'street facing' businesses included prime brokerage, ${ }^{12}$ investment banking and investment management. ${ }^{13}$ As we know from the cases discussed in detail later in this paper, it also traded extensively in OTC derivatives. In addition, it had very significant dealing with client property, which was ultimately held by a web of depositories, exchanges, affiliates, clearing systems and sub-custodians. ${ }^{14}$ LBIE also played a pivotal role in proprietary trading and diverse intra-group transactions. ${ }^{15}$ Moreover, 'it was a main repository for the property of its affiliates in connection with their activities in Europe'. ${ }^{16}$ As an indication of the sheer complexity of its dealings, at the time of the collapse, LBIE had a reported 700 bank accounts, ${ }^{17} 140,000$ failed or pending trades ${ }^{18}$ and 1,707 account holders

10 ibid,[11].

11 ibid, [34(ii)]. Emphasis added by the Court.

12 See the discussion of LBIE's businesses in paragraph 2.5 of the parties' statement of agreed facts reproduced in LBIE, n 2 above, [49]. This describes how LBIE provided prime brokerage services across Europe, US and Asia, providing clients with trade execution, clearing and settlement, custodial and reporting services, OTC derivatives, and secured lending of cash and stock.

$13 \mathrm{ibid}$, describing the six divisions of LBIE: prime services, investment banking, equities, fixed income, investment management and principal investing.

${ }^{14}$ Re Lehman Brothers International (Europe) [2009] EWHC 2141 (Ch), [7].

${ }^{15}$ For e.g., the intra-group transactions that were considered in Re Lehman Brothers International (Europe) [2011] EWCA Civ 1544 (the 'Rascals' litigation). LBIE also put together deals involving other Lehmans entities. For example in Anthracite Rated Investments (Jersey) v Lehman Brothers Finance SA [2011] EWHC 1822 (Ch) LBIE 'devised and marketed' two investment products, both based on 'large and complex structures' [2], including derivatives entered into by Lehman Brothers Finance SA, and guaranteed by LBHI, at [1]. In the same vein, the Extended Liens litigation (see n 16, below) arose because LBIE held securities for Lehmans affiliates. As discussed in July 2011 decision on an interim application in relation to this matter, the 'immensely complicated affairs of the Lehman group' meant that the affiliates were uncertain which side of the argument to advance in the context of this application (Re Lehman Brothers International (Europe) [2011] EWHC 2022 (Ch) [5] and [8].

${ }^{16}$ Re Lehman Brothers International (Europe) [2012] EWHC 2997 (Ch), [7] (hereafter, the 'Extended Liens' decision). Transactions between Lehmans affiliates were often linked to LBIE's client business. For e.g., LBIE entered into derivatives with LBF to off-set LBIE's client positions and shift the risk to LBF, as seen in Lehman Brothers International (Europe) v Lehman Brothers Finance S A [2013] EWCA Civ 118 (hereafter, the 'Back to Back Transactions' decision).

${ }^{17}$ CASS7 First Instance, n 2 above, [49] at paragraph 2.20 of statement of assumed facts.

${ }^{18}$ Re Lehman Brothers International (Europe) [2008] EWHC 2869 (Ch), [22]. 
were thought to have potential claims against LBIE for the return of trust property. ${ }^{19}$

LBIE entered administration at 7.56am London time on 15 September 2008 (i.e., shortly after LBHI). ${ }^{20}$ In the ordinary course of events, dealings between LBIE and affiliates and clients took place, it seemed, without a great deal of attention often being paid to the precise ownership or location of property. ${ }^{21}$ This all changed with the onset of insolvency. Now, LBIE's counterparties rushed to establish their proprietary rights in order to extract their assets from the administration and thereby avoid the fate facing unsecured creditors. As the Court of Appeal pointed out in the 'Rascals' decision, complex arrangements whose legal effects had mattered little when the group was solvent were now subject to interpretation on a 'strict' basis. ${ }^{22}$ This urgent hunt for proprietary rights was made even more complex because, as became apparent over the course of the litigation, LBIE's day-to-day operations were not always performed as they should have been. Mr Justice Briggs observed that the background to one application was the 'imperfect and hugely complex real world occupied by LBIE and it numerous creditors'. ${ }^{23}$ The most notable example to have featured in the case law to date was LBIE's failure to segregate its clients' assets, which was described as 'spectacular'. ${ }^{24}$

For all of these reasons, the LBIE administration has proved remarkable for its 'enormous size and complexity'. ${ }^{25}$ Unsurprisingly in these circumstances, it has generated a stream of cases in the Chancery Division of the High Court. The majority have originated by way of the administrators of LBIE's statutory right to apply to the court for 'directions in connection with his functions'. ${ }^{26}$ Indeed, the

\footnotetext{
${ }^{19}$ Re Lehman Brothers International (Europe) [2009] EWCA Civ 1161, [8].

${ }^{20}$ CASS7 first instance, n 2 above, [49] at paragraph 2.7 of statement of assumed facts. The relative timing of the collapse of LBHI and LBIE is discussed in Lomas v JFB Firth Rixson Inc [2010] EWHC 3372 (Ch), [30].

${ }^{21}$ For example, the automated Rascals system continued to operate for some time after the insolvency of LBIE, until it was turned off on 23 September 2008. Rascals, $n 15$ above, [14].

${ }^{22}$ Rascals, n 15 above, [17]. This process, which was so heavily scrutinised in the course of the litigation, was entirely an internal book-keeping exercise: as regards outsiders, LBIE remained the owner of the securities throughout, ibid [16].

${ }^{23}$ CASS7 first instance, $\mathrm{n} 2$ above, [7].

${ }^{24}$ For example, for the purposes of this application, Mr Justice Briggs was invited to assume that LBIE failed 'on a truly spectacular scale' to segregate the client money of its own affiliates. As a result, there was a shortfall between client money claims and actual segregated client money of around a billion dollars, ibid [4].

25 ibid, [46]. Details of the administration of LBIE have been very helpfully documented in ten (so far) progress reports published by the administrators of LBIE, available at http://www.pwc.co.uk/business-recovery/administrations/lehman/lehmans-joint-administratorsprogress-report-140409.jhtml (last accessed 20 December 2013).

26 Pursuant to paragraph 63 of Schedule B1 to the Insolvency Act 1986. Note that the administrators' position as regards the questions they bring to court varies. In some applications, the administrators were neutral; for example in CASS7 case, they were described by the judge as having 'proffered submissions, in effect, as amic' on most of the issues. CASS7, n 2 above, [22]. In other applications, they were 'by no means neutral'; for example one application took 'the form of a straightforward adversarial contest between LBIE, acting by the Administrators, and LBF, acting by its own insolvency office holders.' Lehman Brothers International (Europe) v Lehman Brothers Finance SA [2012] EWHC 1072 (Ch), [3] (successfully appealed in the Back to Back Transactions appeal, n 16 above). The administrators resisted
} 
use of this statutory right goes a long way towards explain the volume of English decisions arising out of the Lehmans insolvency over the last five years. Of the eight Lehmans matters that have proceeded to the Court of Appeal or further since 2008, all but two were originally initiated by applications on behalf of the administrators. ${ }^{27}$

The administrators' applications not only affect the quantity but also the qualities of judgments, specifically by making them more comprehensive in significant ways. First, various representative parties were often joined to proceedings in order to set up an adversarial hearing on an issue and represent different stakeholders' interests. ${ }^{28}$ In some cases, third parties were also represented in order to assist the court, including ISDA as Intervenor in the Lomas cases, the FSA in the CASS7 cases, and the London Investment Banking Association in the Scheme of Arrangement cases. Secondly, more parties and more lawyers mean more written submissions and more authorities (for instance, no fewer than 11 files of authorities were provided to the court in the Extended Liens case). Thirdly, the value ${ }^{29}$ and complexity of the issues, as well as the number of parties, helped to sustain long, and apparently productive, hearings. ${ }^{30}$ While hearings of considerable duration are far from unusual in commercial cases, a common driver is the high number of witnesses of fact, for example as seen in misrepresentation claims such as Standard Chartered Bank. ${ }^{31}$ However, in several of the LBIE applications, statements of fact were agreed by the parties, and the long hearings were devoted entirely to submissions on questions of law. ${ }^{32}$

early applications for information and/or assets by LBIE clients in RAB Capital, $\mathrm{n} 4$ above and LIBE, $\mathrm{n}$ 18 above. At first instance in the Rascals litigation, the judge described the hearing as a 'straight adversarial fight between LBIE and 5 of its affiliates' Re Lehman Brothers International (Europe) [2010] EWHC 2914, [25].

${ }^{27}$ The two appeals not originally initiated by applications by the administrators are Belmont, $\mathrm{n} 6$ above and Trustees of Lehman Brothers Pension Scheme v Pensions Regulator [2013] EWCA Civ 751.

${ }^{28}$ Note that in order for the court to be able to determine such issues, these applications require 'parties ready either in their own interests or on a representative basis to argue each relevant corner.' Extended Liens disclosure application, Re Lehman Brothers International (Europe) [2011] EWHC 2022 (Ch), [14]. In this case, '[t]he court's requirement, in order to deal effectively with the issues raised, is that there should be identified parties prepared to argue, in summary, for and against Extended Liens'. Ibid. 'Representative' litigants were also replied upon in Re Lehman Brothers International (Europe) [2009] EWHC 2545 (Ch) (hereafter, 'MCF') and in the CASS7 litigation. The latter included representatives from a 'spectrum of competing interests' CASS7 first instance, $\mathrm{n} 2$ above, [23].

${ }^{29}$ See, for e.g., n 24 above.

${ }^{30}$ For e.g., there were six days of legal argument as well as 11 files of authorities in the Extended Liens case, $\mathrm{n} 16$ above. At ibid, [6] the judge praises the process for drawing out the legal issues. The first instance hearing in Rascals took the best part of three weeks (Referenced in the CA decision, Rascals, $\mathrm{n}$ 15 above [2])

31 Standard Chartered Bank v Ceylon Petroleum Corporation [2011] EWHC 1785 (Comm). In this case, the claimant called eight witnesses of fact and submitted a written statement from a ninth, while the defendant called 10. In addition, each side called a Sri Lankan law expert. [55]-[56], [66] and [392].

32 I.e., where the court is invited to base its decision on statements of fact agreed by the parties for the purpose of the hearing only. See, for e.g., Extended Liens, n16 above, [4]. The trial of two closely related Part 8 claims in Anthracite, n 15 above, also proceeded on the basis of agreed facts. In the CASS7 litigation, the legal issues were also determined on the basis of assumed facts. The CASS7 decision confirmed that this was 'relatively unusual'. CASS7 first instance, n 2 above, [48]. Helpfully, the statement 
The substantive effects of this narrowly-focused and highly intensive type of hearing are evident across the Lehman decisions. The Extended Liens decision is a good example. ${ }^{33}$ Here, a fundamentally important question about the treatment of floating charges under the Financial Collateral Arrangements (no 2) Regulations 2003 ('FCAR') presented itself in the course of an application about the effects of an intra-group security document. This question had been troubling academics and practitioners for some time, because it was never quite clear how floating charges fitted into the UK collateral regime established in order to implement the Financial Collateral Directive ('FCD'). ${ }^{34}$ There had been one English decision on the applicability of the FCAR to floating charges before the Extended Liens case, but it was not regarded as definitive, bearing in mind the importance of this point of law. Indeed, Briggs J expressly contrasts the Extended Liens case with this decision, Gray v GTP Group,35 which was a 'short hearing about a low-value matter'. ${ }^{36}$ In the Lehmans case, submissions explored in great detail matters including the travaux préparatoires of the FCD and the academic commentary, ${ }^{37}$ with the overall effect that the judge considered himself in a position to sidestep Gray and rule on these questions afresh in Extended Liens. ${ }^{38}$ Similarly, in the substantial 'Back to Back Transactions' decision, the Court of Appeal noted that there had hitherto only been one authority on the 2002 (as opposed to 1992) MA. Like Gray, this earlier matter was a relatively small dispute, which was in fact resolved at the summary judgment stage (BNP $v$ Wockhardt). ${ }^{39}$ In short, there was no authority prior to this Lehmans case on the fundamentally important early termination provisions of the 2002 version of the ISDA MA. ${ }^{40}$ Seen in this way, the LBIE administrators' applications created rare opportunities for the courts to rule on several fundamentally important questions of financial law, and, what is more, the nature of the applications enabled them to do so with the benefit of lengthy and expert submissions.

and supplements are reproduced almost in full in this judgment, at [49]. Not all the Lehmans decisions proceeded on this basis, however. For e.g., in Rascals, some facts were agreed, some were disputed. Rascals first instance, n 26 above, [38].

${ }^{33}$ Extended Liens application, $\mathrm{n} 16$ above.

34 2002/47/EC. This matter is discussed, for e.g., in J Benjamin, Financial Law (OUP: 2007) [20.112][20.117], noting that 'London industry voices' had called upon the European Commission to clarify the status of floating charges under the Financial Collateral Directive.

35 [2010] EWHC 1772 (Ch). In this case, Vos J held that the terms in question did not confer legal control to the collateral taker. Legal, rather than merely administrative, control was need for the charge to qualify under FCAR.

${ }^{36}$ Extended Liens, n 16 above, [135]. At ibid, [118] Briggs J confirms that the judge in Gray did not have 'anything approaching the depth and detail of the legal argument deployed in this present case'.

37 ibid [74]-[148].

38 ibid [127]. Although Briggs J ultimately held that the security rights conferred by the LBIE-LBF Master Custody Agreement fell short of qualifying under FCAR, his reasoning opens up the possibility for a floating charge qualifying in ways Vos J's decision did not. For instance, Briggs J held that the charge for LBIE's own debts would have qualified had it stood alone, see ibid [144].

${ }_{39}$ Back to Back Transactions, Court of Appeal, n 16 above, [56], mentioning BNP v Wockhardt [2009] EWHC 3116, but confirming it 'is not relevant' to the questions in hand.

${ }^{40}$ Back to Back Transactions, at first instance, n 26 above, [39]. 
The objectives of the administrators' applications also make the decisions more thorough than those arising in a more typical adversarial context. ${ }^{41}$ Because the administrators' intention was to apply the decisions in various contexts in the administration (i.e., the decisions were to serve as a form of precedent within the administrative process), ${ }^{42}$ they requested that judgments deal with moot points, alternatives ${ }^{43}$ and even points which the parties had already settled. ${ }^{44}$ It is striking that the courts seemed to comply with virtually all of these requests, making for unusually comprehensive decisions. What appears to be a higher than usual prospect of appeal also seemed to have had this effect at first instance. Of course, this is not to say that these decisions all went the way the administrators were hoping; the Court of Appeal's rejection of the administrators' Scheme of Arrangement case shows as much. Rather, it is clear, first, that the administrators' statutory applications account for the bulk of the English Lehmans-related case law, and secondly, that the fact that all this time and effort was spent to 'seek the courts' guidance'45 had a clear and substantive effect on the decisions which were handed down as a result.

\section{STANDARDISED CONTRACTS}

The second factor explaining the unusual precedential effects of the Lehman decisions is the nature of the contracts in dispute. These contracts can collectively be described as 'standardised financial contracts', where this term includes both trade association drafted agreements, such as the ISDA Master Agreement, International Prime Brokerage Agreement, or 'industry standard' repo documentation ${ }^{46}$ and the standardised contracts used within the Lehmans group, such as the Master Custody Agreement considered in the Extended Liens decision. ${ }^{47}$

Many standardised financial contracts offer English law and the English courts as default choices, or one of the default choices. ${ }^{48}$ For example, this is the

\footnotetext{
${ }^{41}$ E.g., as seen in Gray or BNP, discussed in n 35 and n 39 above.

${ }^{42}$ E.g., in the Back to Back Transactions application, the administrators were seeking a ruling they could apply to many contracts rather than a ruling on any one scenario in particular. It was noted by the Court of Appeal that the administrators 'are concerned that there are or may be security rights against other entities than LBF governed purely by agreements in the same form as the STB'. Back to Back Transactions, Court of Appeal, n 16 above, [216].

${ }^{43}$ E.g., Extended Liens application, n 16 above, [51]-[53] comments on the position were an earlier part of the decision held to be incorrect on appeal.

44 ibid, [241], where the judge decides a point which settled between the end of the hearing and judgment. The reason given was that the parties wanted a judgment which addressed issues including those not strictly necessary to my decision'.

${ }^{45} \mathrm{MCF}, \mathrm{n} 28$ above, [1].

${ }^{46}$ Discussed in Rascals and described as 'industry standard terms' at [15] of the first instance judgment, $\mathrm{n}$ 26 above, and in the Court of Appeal decision, n 15 above, [11].

47 The latter category is routinely described as 'standard contracts' in the Lehmans case law, e.g. the MCA and STB in issue in the Extended Liens application are described a 'two standard form documents' Extended Liens, n 16 above, [1].

48 As noted in a recent ISDA publication:
} 
case in the 1992 and 2002 ISDA Master Agreement. Across complex transactions, this ensures consistency; for instance, all of the relevant parts of the 'complex web of contractual documentation' in the Belmont transaction were governed by English law. ${ }^{49}$ As a result of such drafting, foreign businesses are routinely pulled into this jurisdiction when contractual disputes arise. ${ }^{50}$ This helps to explain the origins of several of the English Lehman decisions that were not generated by the LBIE administrators' applications. ${ }^{51}$

Having drawn the disputes into the English courts, standardised contractual subject-matter then adds a further dimension to a decision's precedent-setting potential. Because standard terms are litigated relatively rarely and the knock-on effects are so far-reaching, even first instance decisions interpreting such documentation (such as the Extended Liens application) attract very keen attention. In response, judgments often openly express a sense of responsibility to parties beyond the courtroom doors. This is apparent, for example, in decisions interpreting terms like the Close-out Amount provisions of the 2002 ISDA MA52 or considering the 'purpose' element of the 'security financial collateral arrangement' definition in the FCARs. ${ }^{53}$ This weight of expectation, whether originating from LBIE administrators intending to use judicial decisions as tools in their work, or from the users of standard terms more broadly, results in judgments that are both more comprehensive in terms of the law, and more sensitive to the dynamics of the global financial markets.

\footnotetext{
'Historically, international financial transactions have tended to be documented under agreements governed by English or New York law and which contain jurisdiction clauses conferring jurisdiction on the English or New York courts. These are, of, course, the options provided for in the 1992 and 2002 ISDA Master Agreements.'

ISDA, Memorandum for Members of the International Swaps and Derivatives Association, Inc., The use of arbitration under an ISD A Master Agreement, (ISDA, 10 November 2011) 4.2.

49 Belmont, n 16 above, [10]. See also Lehman Brothers Commodity Services v Credit Agricole Corporate and Investment Bank (formerly Calyon) [2011] EWHC 1390 (Comm), where the Letter of Credit and ISDA MA between the claimant and EDF were both subject to English law. In Rascals, the web of contracts involved were governed by English, NY and Swiss law but the court was invited to assume for all, bar the NY contract, that interpretation under foreign law would arrive at the same outcome as if they were governed by English law. Rascals, first instance, $\mathrm{n} 26$ above [112].

50 Though sometimes parties contest jurisdiction in these circumstances. See, for e.g., LB Bankhaus v $C M A$, [2013] EWHC 171 (Comm), where the 'Settlement Contract' between a Germany Lehman affiliate and French company was governed by English law and gave exclusive jurisdiction to the English courts, but following an application by CMA, the judge stayed English proceedings pending the final outcome of proceedings in France.

${ }^{51}$ E.g., Lehman Brothers Special Financing v Carlton Communications [2011] EWHC 718 (Ch), which involved a dispute between Delaware based LBSF and a UK company over the 1992 MA, and Anthracite, n 15 above, between LBF and purchasers of structured products.

52 Back to Back Transactions, n 16 above.

${ }^{53}$ Extended Liens, n 16 above. At [98], the judge rejects problems raised with 'purpose' part of test of a security interest qualifying under FCARs, on the basis that setting such precedent would impose formality and increase risk across the markets, having exactly the opposite of the intended effect of the FCARs.
} 


\section{Summary}

The table below shows four levels on which the English courts' Lehman-related decisions have a precedential effect. Two levels are highlighted to draw attention to the particularly broad effects of cases generated by this insolvency.

Table 1: Lehmans case law, and levels of precedential effect:

\begin{tabular}{|c|c|c|}
\hline $\begin{array}{l}\text { Impact of Lehmans } \\
\text { decision: }\end{array}$ & $\begin{array}{l}\text { Parties affected by } \\
\text { precedent: }\end{array}$ & Example: \\
\hline $\begin{array}{l}\text { Specific Lehman Brothers } \\
\text { arrangement }\end{array}$ & Litigants & $\begin{array}{l}\text { Lehman Brothers Bankhaus v CMA } \\
\text { [2013] EWHC 171: jurisdiction } \\
\text { dispute, Articles } 27 \text { and } 28 \text { of EC } \\
\text { Regulation } 44 / 2001 \text { discussed. See } \\
\text { discussion in text accompanying n } \\
\text { 50. }\end{array}$ \\
\hline $\begin{array}{l}\text { Similar Lehman arrangements } \\
\text { within the administration }\end{array}$ & $\begin{array}{l}\text { Creditors, } \\
\text { beneficiaries of } \\
\text { LBIE, including } \\
\text { Lehman affiliates }\end{array}$ & $\begin{array}{l}\text { Re Lehman Brothers International } \\
\text { (Europe) [2012] EWHC } 2997 \text { (Ch): } \\
\text { the 'Extended Liens' application, } \\
\text { brought by administrators of LBIE } \\
\text { seeking guidance on this and similar } \\
\text { LBIE contracts. See discussion in } \\
\text { text accompanying n } 43 \text {. }\end{array}$ \\
\hline $\begin{array}{l}\text { Standardised financial } \\
\text { documents }\end{array}$ & $\begin{array}{l}\text { Users of standard } \\
\text { form documents, } \\
\text { trade association as } \\
\text { 'keepers' of } \\
\text { standardised } \\
\text { documents. }\end{array}$ & $\begin{array}{l}\text { Re Lehman Brothers International } \\
\text { (Europe) v Lehman Brothers Finance SA } \\
\text { [2013] EWCA Civ 188: ruling on } \\
\text { interpretation of Close-out Amount } \\
\text { under } 2002 \text { ISDA MA/ side letter. } \\
\text { First case to look at these provisions } \\
\text { of } 2002 \text { MA. See discussion in text } \\
\text { accompanying n } 39 \text { and n } 96 .\end{array}$ \\
\hline English common law & $\begin{array}{l}\text { All parties subject to } \\
\text { relevant provisions } \\
\text { of English law. }\end{array}$ & $\begin{array}{l}\text { Belmont Park Investments Pty Ltd v } \\
\text { BNY Corporate Trustee Services [2011] } \\
\text { UKSC 38: considered and applied } \\
\text { the anti-deprivation principle. See } \\
\text { discussion in text accompanying n } \\
100 .\end{array}$ \\
\hline
\end{tabular}




\section{LAW AFTER LEHMANS}

Having observed that the English courts' decisions on Lehmans-related cases enjoy unusually high precedent-setting potential, the next stage is to consider what their effects have been. On 10 October 2013, the LSE Department of Law and the LSE Law and Financial Markets Project organised a workshop, 'Law after Lehmans', to mark the fifth anniversary of the collapse of the Lehman Brothers group. The objective was to use this vantage-point to start to review the case law and consider its effects. Attendees and speakers were drawn from academia, the Bar, law firms, the accountancy profession, and the judiciary. In addition to opening and closing addresses from speakers involved in the administration and its aftermath, panels were organised to discuss property rights, contractual interpretation and insolvency law. The workshop took place subject to the Chatham House Rule. ${ }^{54}$ In keeping with the terms of engagement, the discussion below identifies some of the general themes that emerged from the workshop, but it does not identify speakers or participants at the event. ${ }^{55}$

\section{Property Rights AFter LeHMANS}

The Lehman Brothers group's collapse triggered a global scramble to establish property rights, so that counterparties could avoid the fate of unsecured creditors. This competitive exercise forms the backdrop for a significant number of the Lehman Brothers decisions handed down by the English courts (see Appendix 2 to the paper, sections 4 and 5). It also accounts for some of the most factually complex and legally challenging cases, for instance, where contracts proved to be inadequate in light of subsequent events. Two main themes emerged from the discussion about the application of proprietary principles in these cases.

The first concerned the manner in which proprietary principles were deployed by judges tackling the complex, grave and time-sensitive ${ }^{56}$ problems on which the Lehmans administrators sought guidance. At stake in MCF, for example, was a 'substantial cash mountain' held by LBIE and by sub-custodians, of which LBIE alone held $\$ 1.8$ billion. ${ }^{57}$ In this case, the prime brokerage client's fate 'graphically illustrated' the difference between having property rights and a

\footnotetext{
${ }^{54}$ Whereby 'participants are free to use the information received but neither the identity nor the affiliation of the speaker(s), nor that of any other participant, may be revealed'. Available at http://www.chathamhouse.org/about-us/chathamhouserule (last accessed 5 February 2014).

55 This is solely the author's account. It does not purport to summarise the speakers' presentations, nor has it been approved by them. The objective is to report and contextualise general themes emerging from the discussion, which were debated by participants on the day, rather than to record the content of any individual presentations.

${ }^{56}$ E.g., see LBIE, n 18 above, which was an application by four private funds seeking information about their assets from the LBIE administrators. The funds were allowed to remain anonymous for the purpose of the application, as their evidence claimed their viability was at stake if they could not recover their assets promptly [14].

${ }^{57}$ MCF, n 28 above, [16].
} 
mere personal claim. 58 90\% of MCF's assets were represented by two US T-Bills, held by LBI as sub-custodian for LBIE. The first matured on 18 September 2008 and the second on 11 December 2008. If the IPBA were held to apply to this cash, MCF would have gone "from being the beneficial owner of a securities portfolio worth $\$ 50$ million to being the holder of an unsecured debt for the same nominal amount against the (probably) deeply insolvent LBIE [...]'.59

Trusts law was deployed flexibly in response to the problems presented by various Lehmans cases. In MCF, counsel for the unsecured creditors argued that there was 'no trust known to English law' 60 over the clients' securities held by the prime broker, because the securities were held in fungible accounts, mixed with those of other customers, and LBIE (the prime broker) was subject only to an obligation to redeliver equivalent securities, and could even refuse to implement the client's instructions. Further, the securities were subject to a Right of Use, whereby LBIE could do anything it liked with them, without notice and for its own profit. However, the judge considered the nature of the asset-holding arrangements in detail, and found nothing inconsistent with the existence of a trust. On the question of omnibus fungible accounts, for instance, he held that if client securities were held in such accounts, mixed with the equivalent securities of other counterparties, this did not destroy the clients' proprietary rights. Rather, clients may have instead 'a rateable share in the fungible account rather than in particular securities in that account'. ${ }^{61}$ The Right of Use granted to LBIE by the clients was more difficult to square with the trust relationship. On the face of it, the trustee's power to treat the assets as its own was, as the judge conceded 'a powerful contra-indication of a trustee/ beneficiary relationship'. ${ }^{62}$ Nonetheless, based on an approach variously described as 'purposive and commercial analysis', ${ }^{63}$ and viewing 'the Agreement as a whole' and 'broadly', ${ }^{64}$ the judge concluded that the Right of Use could be seen as the trustee's right to swap trust property 'for equivalent property of its own'. ${ }^{65}$ In short, the Right of Use failed to defeat what the judge saw as 'otherwise clear indications of an intention to create the relationship of trustee and beneficiary between Prime Broker and Counterparty $[\ldots]$ '. ${ }^{66}$ As the decision notes, this makes for 'a most unusual type of trust'. ${ }^{67}$

Property rights were equally stretched in the course of other Lehmans cases. Indeed, it was suggested at the workshop that the determining factor in identifying

\footnotetext{
58 ibid, [19].

59 ibid, [20].

60 ibid, [52].

61 ibid, [56].

62 ibid, [63].

63 ibid, [62].

64 ibid, [64].

65 ibid, [61].

66 ibid, [64].

${ }^{67}$ ibid, [52].
} 
property rights may now simply be the parties' belief that they have them. In Rascals, an application was made by the administrators in relation to LBIE's global settlement business, whereby it stood as the hub company for all securities bought and sold by the group in Europe. This practice meant that LBIE traded securities in Europe on its own behalf and on behalf of Lehmans affiliates, based anywhere in the world. ${ }^{68}$ The matter before Court of Appeal related to the beneficial ownership of securities bought by LBIE on behalf of its affiliate, LBF, where the purchased securities were subject of a regulatory capital-driven, intra-group repo scheme called Rascals. Under this scheme, LBIE acquired securities for its affiliates, which it held on trust for them. ${ }^{69}$ The Rascals process then implemented a series of daily repos between LBIE and LBF, which took effect until the securities were re-sold back to the street. This meant that once LBIE bought securities for its affiliate, the parties agreed to the immediate sale of LBF's interest in the security back to LBIE. The following day, there was to be a sale back of an equivalent security by LBIE to the affiliate (at the same price plus interest), with LBIE having the right of use of the security in the meantime. Significantly, the various sums were not cash-settled between the parties but paid by 'a series of successive offsets'.$^{70}$ The question brought by the administrators to the court was which party enjoyed beneficial title in the securities on insolvency.

The Court of Appeal agreed with the judge and found that beneficial title was transferred by the affiliate to LBIE under the on-leg of the repo. This conclusion was reached not because there was payment by $\mathrm{LBIE}^{71}$ but because the affiliate was estopped by common convention from denying that there had been payment. ${ }^{72}$ In other words, the decisive factor was that the parties had treated as payment as being made, even though the documentation 'would have led to a different result as regards securities acquired after June 2000'.73 Similarly, LBF was 'treated as paying the price on the off-leg of the first repo when, and not until, the next repo opened'. As a result '[b]eneficial title to the securities passed to LBIE under the on-leg of the first repo, and remained vested in LBIE throughout the Rascals process until a resale to the street'. ${ }^{74}$ On insolvency, therefore, it was LBIE that enjoyed the beneficial title in the assets rather than the affiliate. In discussion, this case was flagged up because it marked the parties' treatment of proprietary rights being held up by the court as determinative. A link was drawn with the modern approach to contractual interpretation. It was regarded as a cause for concern that this case law seems to prioritise what the parties seek to achieve over what they have done. The concern was expressed that, in the long-term, cases like MCF and Rascals threaten to undermine the certain operation of property rights, particularly on an insolvency, which is when they matter most.

\footnotetext{
${ }^{68}$ Rascals, Court of Appeal, n 15 above, [5].

${ }^{69}$ ibid [62]-[78].

70 ibid, [11], citing the first instance decision, n 26 above, [14].

${ }^{71}$ Rascals, Court of Appeal, n 15 above, [84]-[86].

72 ibid [105]-[126].

73 ibid [126].

74 ibid [133].
} 
The second theme to emerge out of the discussion of property rights and the Lehmans cases concerned the protection of client assets. Specifically, the workshop addressed the Supreme Court's widely-criticised decision on client assets, and discussed the lessons of the Lehmans cases for the ongoing reforms of the UK regime.

The factual background to the this litigation was not only the Lehman group's insolvency, but the prior failure of LBIE to comply with the client money rules in chapter 7 of the Client Assets Sourcebook (CASS7). As Mr Justice Briggs put it, at first instance,

[t] he combination of a massive failure to identify and segregate client money, coupled with the credit loss shortfall attributable to the [affiliate where LBIE had deposited $\$ 1$ billion of segregated client money] has thrown up a series of fundamental problems in the interpretation and application of the rules in CASS7 to LBIE's business and insolvency. ${ }^{75}$

One of the principal questions for the court was whether, for the purpose of CASS 7.9.6R, clients' money should include only that which had been segregated or whether it included both segregated and unsegregated money. Further, the court was asked to decide whether a client's entitlement to share in this pool was on a contractual claims basis or on the basis of having a proprietary interest in the pool.

The Supreme Court held by a majority of three to two (Walker and Hope LJJ dissenting) that the client money which fell to be distributed on a 'primary pooling event' included all client money, and not just that which had been segregated. Furthermore, the majority held that there was a 'formidable textual argument' that client money was to be shared by "each client" of the firm, so that all clients with a "client money entitlement" are entitled to share'. ${ }^{76}$ In other words, a 'purposive interpretation' 77 was applied to establish that rules were intended to protect all clients, not just those whose money had actually been segregated. The claims basis was therefore upheld, over the alternative proprietary (or contributions) basis.

This decision has been severely criticised, including on the basis that clients with a mere contractual entitlement have no basis to be permitted to participate in the pool of segregated money under either the CASS7 rules, or in general law. It was submitted that the decision was driven by a concern to safeguard all clients' interests, but at the cost of disrupting the security of segregated assets. The knockon effects were swiftly seen in the 2012 Extended Liens case, where the judge noted that he could 'envisage that there may be some difficult questions of detail arising out [for the Master Custody Agreement at issue] of the decision of the

75 CASS7 First Instance, n 2 above, [7].

${ }^{76}$ Re Lehman Brothers International (Europe) [2012] UKSC 6 (hereafter 'CASS7 Supreme Court') [155]-[157]. Emphasis in the original.

77 ibid, [159]. 
Supreme Court in the Client Money case', though on that occasion, he decided he did not have to pursue these questions further. ${ }^{78}$

In practical terms, the Supreme Court's decision to uphold the claims basis caused increased costs and significant delay in the return of client assets. PWC reports that it has taken over four years to return client assets in the LBIE insolvency. ${ }^{79}$ Furthermore, since the Supreme Court decision, the regime has been applied in the MF Global, Pritchards and WSL insolvencies and, according to the FCA, interim distributions in those cases have taken 'months or years' and 'such distributions are often limited percentages of the recovered client money'. ${ }^{80}$ The FCA observes that the LBIE decision has increased delays principally because it demands that administrators have to quantify clients' entitlements, verify claims, and go to court to resolve hard cases, especially in light of administrators' personal liability. It was suggested at the LSE event that separate trustees should be appointed to separate out the interests of clients and unsecured creditors in such challenging circumstances. There are, therefore grave legal and practical implications of the Supreme Court's decision for all sorts of participants in the financial markets, and, in particular, for the 1,500 parties regulated by the FCA which are permitted to hold client assets and/ or client money, ${ }^{81}$ including clearing houses, prime brokers and custodians.

It is unsurprising, therefore, that the Supreme Court decision has had a direct effect on the FCA's ongoing review of the rules on client money, custody assets and mandates. The FCA's proposals are wide-ranging (some, for instance are a response to EMIR's rules about clearing houses) but in part they are an attempt to address problems highlighted by this Lehmans case, including the difficulties and severe delays in returning client money. Indeed, the FCA goes so far as to use the facts of the CASS7 case to demonstrate how its proposed new approach of having an initial and a residual client money pool (or a combined approach) would work more speedily for clients. ${ }^{82}$

The FCA powers are limited, however, and it was suggested at the LSE event that it may be time for a more radical re-thinking of the rules protecting client assets. Tellingly, at the end of its discussion of the CASS7 case and this aspect of the 'current regime', the FCA acknowledges that '[m]ost of the matters we refer to above are beyond our remit; however, in our speed proposal we discuss what we can achieve given the above matters and the limits of our powers'. ${ }^{83}$ Against this background, the LSE event discussed whether it was time for a more fundamental review of the basis of the English regime, and in particular, its reliance on the traditional rules of trusts to distinguish between personal claims and property

\footnotetext{
${ }^{78}$ Extended Liens, n 16 above, [176].

${ }^{79}$ FCA, Review of the client assets regime for investment business, Consultation Paper CP/13, (July 2013), [2.27], referencing PWC's ninth progress report. Available at http://www.fca.org.uk/yourfca/documents/consultation-papers/cp13-5 (last accessed 20 December 2013).

80 ibid, [2.10].

81 ibid, [1.8].

82 ibid, [2.27].

83 ibid, [2.13].
} 
rights. One pressing problem cited with this approach, in addition to the lengthy delays mentioned already, was that it leaves clients with a considerable exposure to any shortfall in the pool. Further, it was a submitted that the rules about the identification of trust property and tracing are extremely difficult to apply in the context of financial transactions, especially given the interchangeability of assets, international nature of the markets, and the ubiquitous right of use. This argument was further developed by way of a comparison with the US regime, where clients are protected by way of statutory priority.

In conclusion, the discussion at the LSE event observed how the English courts took a flexible approach to property rights in an attempt to safeguard clients' interests in this challenging context. The discussion, however, suggested that this was far from ideal from the point of view either of the long-term certainty of proprietary principles or the realities of insolvency practice. It might, therefore, be time to acknowledge that, even when stretched this far, proprietary principles are not the best way of protecting clients exposed to insolvencies in the modern financial markets.

\section{CONTRACTUAL INTERPRETATION AFTER LEHMANS}

Many Lehman decisions required the court to engage in contractual interpretation. Litigation about property rights, noted above, threw up questions of contractual interpretation, for example, where the court was required to determine if parties to a contract had intended a trust to arise. Other interpretation cases centred on the meaning of terms regarding payment and termination on insolvency. For instance, the courts were required to decide how the Non-defaulting Party's payment obligations under the ISDA MA were affected by a Lehman entity's continuing insolvency. In other, ongoing litigation, the court has been asked to consider the interplay of contractual agreements and insolvency rules in order to determine which has priority, out of a claim under a subordinated debt instrument and postadministration interest. ${ }^{84}$ Stepping back, can any themes be identified from the contractual interpretation aspects of these diverse decisions?

One common denominator is the subject-matter of many of these interpretative exercises, which may be described as standardised financial contracts. The paradigm standardised financial contract is the ISDA Master Agreement, which was considered (within this set of Lehmans cases) in the Lomas litigation, the Back-to-Back Transactions cases, Calyon and Anthracite Rated Investments (Jersey) Ltd (as set out in Appendix 2 to the paper, sections 3 and 6). As discussed at the LSE event, when the court is asked to interpret a term that is

${ }^{84}$ The so-called LBIE 'Waterfall Application'. Hearings took place between 12 and 20 November 2013; at the time of writing, judgment is still reserved. Transcripts of the daily hearings are available at http://www.pwc.co.uk/business-recovery/administrations/lehman/update-waterfall-applicationsubordinated-debt-and-other-affiliate-relationship-issues-daily-transcripts-of-the-hearing-nov-2013.jhtml (last accessed 20 December 2013). 
part of such a widely-used, and, as some academics put it, transnational, 85 contract the court is effectively playing a regulatory, as well as a dispute resolution, role. Accordingly, the traditional approach to interpreting contractual terms may not always be appropriate. For instance, standard form contracts are not written by the parties but instead by trade associations or other third parties. ${ }^{86}$ The contracts in question in several of the Lehman cases were not even negotiated at arm's length because they were entered into by affiliates. Indeed, in some of these cases, contracts had simply been recycled from one part of the business to another (unsuitable) one, such as happened in the Extended Liens application. ${ }^{87}$ For these reasons, the interpretation of standardised financial contracts in the Lehmans cases presents particular challenges. The discussion about how the courts have responded focused on two main observations.

First, it was discussed how the courts placed considerable weight on the context of contractual terms and, in particular, on the commercial objectives of the overall arrangements. In some cases, this required the courts to hear very detailed oral and documentary evidence in order to construct the 'legal arrangements' in which the standardised financial contracts had been deployed. This process was especially complex where standardised contracts like the ISDA MA had been used as a building block within multi-party legal structures, such as within the Belmont structured finance transaction, or the secured euro MTN programme that was the subject of the Anthracite litigation. ${ }^{88}$ In Rascals, this reconstruction process involved a

minute examination both of the contractual structures put in place $[\ldots]$ and the accounting records employed by the Group for the purpose of recording their financial dealings, including but not limited to those constituted by the Rascals transactions. ${ }^{89}$

In other cases, evidence supplied by third parties was used to help the courts establish the commercial objectives of the arrangements in question. When interpreting the ISDA MA, in particular, the courts refer to a broad range of sources, such as the ISDA's 'Users' Guide' and consultations, ${ }^{90}$ experts, ${ }^{91}$ and

\footnotetext{
85 A Riles, Collateral Knowledge: Legal Reasoning in the Global Financial Markets (University of Chicago Press: 2011); H Collins, 'Regulatory Competition in International Trade: Transnational Regulation through Standard Form Contracts' in H Eidenmuller (ed), Regulatory Competition in Contract Law and Dispute Resolution (forthcoming).

${ }^{86}$ The implications of which for the contractual interpretation process are discussed S J Choi and G M Gulati, 'Contract as Statute' (2005-6) 104 Michigan Law Review 1129.

${ }^{87}$ Extended Liens application, n 16 above, [24]-[25]. In this case, the MCA was drafted for use between LBIE and its street customers. Later, the Taiwanese authorities required documentation to be put in place to record the previously undocumented provision of custody services by LBIE to its affiliates, including LBF. At this point, the 'street-facing' MCA was used to fill the gap.

${ }^{88}$ Belmont, $\mathrm{n} 6$ above; Anthracite, $\mathrm{n} 15$ above.

${ }^{89}$ Rascals, first instance, $\mathrm{n} 26$ above [37].

${ }^{90}$ Back to Back Transactions, Court of Appeal, n 16 above [52]:
} 
practitioner texts ${ }^{92}$. The commercial objective of these arrangements, or at least the version arrived at by the courts, then played a significant role in the outcome of the interpretative exercise. For example, in Rascals, as discussed above, the parties' treatment of their arrangements, as evidenced by accountancy records, prevailed over express words in the ICFA. ${ }^{93}$ In certain cases, therefore, context, once painstakingly assembled, can actually override text. ${ }^{94}$

Secondly, the Lehman decisions, and in particular the Lomas litigation, were discussed from the perspective of the courts' willingness to imply terms. The Lehmans insolvency was unforeseen, including by contractual draftsmen, and so it generated near-perfect conditions in which to study the phenomenon. As Briggs J explains in MCF, referring here to the IPBA,

the Agreement is silent as to what, if anything, should happen in the continued operation of clause 5.2, in the event that the Prime Broker either goes out of business; ceases to perform the prime brokerage service, goes into an insolvency process or does all three of those things simultaneously, as actually occurred in relation to LBIE..$^{95}$

Similarly, in Lomas, the 'parties have made no express provision for what is to happen to suspended obligations when the transaction matures. ${ }^{96}$ In the Back to Back Transactions decision, at first instance, Mr Justice Briggs found that the effects of the insolvency of the LBIE and the subsequent early termination of the Intercompany Transaction was

a matter about which I have not the slightest doubt no one ever gave a moment's thought. The result is that [construction of the transactions] [...] takes place in an unusually perfect cognitive vacuum. ${ }^{97}$

All of this contractual silence might have been expected to have been met by an outbreak of implied terms, but, in practice, this was not the case. In the entire set

'The 2002 Master Agreement must of course be interpreted in the light of the relevant background. That includes the 1992 Master Agreement, the prior case law on the 1992 Master Agreement (not limited to the jurisprudence on the "value clean" principle) and the User's Guide."

[Emphasis in the original].

${ }^{91}$ For e.g., the 'three distinguished expert witnesses who were called to give their opinions on questions of New York law and the Code' in Calyon, n 49 above [12].

92 Such as S Firth, Derivatives: Law and Practice (Sweet and Maxwell: Loose-leaf: Last release August 2013) cited in Lomas v JFB Firth Rixon [2012] EWCA Civ 419 and Carlton, n 51 above.

${ }^{93}$ See discussion accompanying $\mathrm{n} 71$ above.

${ }^{94}$ For a discussion of the contextual approach to contractual interpretation, and a response, see Lord Steyn, 'The Intractable Problem of the Interpretation of Legal Texts' and H Collins, 'Objectivity and Committed Contextualism in Interpretation' in S Worthington (ed.), Commercial Law and Commercial Practice (Hart: 2003).

${ }^{95} \mathrm{MCF}, \mathrm{n} 28$ above, [88].

${ }^{96}$ Lomas, Court of Appeal, n 92 above, [54].

${ }^{97}$ Back to Back Transactions, first instance, $\mathrm{n} 26$ above, [18]. 
of Lehmans cases, there is only one decision where a term was implied into a contract. That case was MCF, where, interestingly, none of the parties had asked for it, but had rather based their submissions on other contractual construction points, assignment and, even on various equitable maxims. The judge, however, preferred the implied term route to establishing what the parties had intended to happen on the prime broker insolvency. He explained, that, in keeping with the Privy Council judgment delivered by Lord Hoffmann in Attorney General of Belize v Belize Telecom $L t d,^{98}$ the implication of terms is one of the facets of contractual interpretation. On this basis, Briggs $\mathrm{J}$ found that the 'reasonable addressee', mindful of the purpose of the contract, would regard there to be 'only one reasonable answer' to the question of what should happen to the proceeds of securities if LBIE stopped performing its functions as prime broker, and that would be for the client to continue to enjoy a beneficial interest in the cash. ${ }^{99}$

Conversely, on the three occasions when litigants did try to persuade the court to imply terms in Lehman contracts, they were unsuccessful each time. What is interesting about the failure of these arguments in Lomas (where the administrators alone suggested four implied terms), Carlton and in the Extended Liens cases is, first, that the courts seem especially reluctant to imply a term when the underlying contract is as widely used and sophisticated as, for instance, the ISDA MA. It was suggested to the LSE event that judicial reluctance to imply terms into such contracts was entirely apt. Secondly, the unsuccessful attempts to imply terms into standardised contracts confirm that a merely inconvenient outcome will not be enough to persuade the courts. This is made clear, for example, in Lomas, where the Court of Appeal quoted Attorney General of Belize to the effect that, where an agreement is silent as to what is going to happen 'the most usual inference in such a case is that nothing is to happen'. ${ }^{100}$ In other words, loss should normally lie where it falls. In conclusion, the Lehmans cases suggest that it will be rare for the courts to imply terms into financial contracts, and rarer still when they are considering sets of very widely used standardised terms.

\section{INSOLVENCY LAW AFTER LEHMANS}

It might fairly be said that every Lehman decision is about insolvency law. With that qualification, however, the LSE event identified several discrete ways in which the litigation arising out of the Lehmans insolvency can be said to have had an impact on the UK's insolvency regime.

First, the Lehmans cases applied and developed a number of common law insolvency principles, some of which had received very little attention in recent years. The most prominent example is the Supreme Court's decision in Belmont, which addressed the meaning and effects of the anti-deprivation principle ('ADP'). This decision drew on precedent going back to the 1860s, which was discussed in

${ }^{98}$ [2009] 1 WLR 1988.

${ }^{99} \mathrm{MCF}, \mathrm{n} 28$ above, [93].

${ }^{100}$ Lomas, Court of Appeal, n 92 above, [56] quoting Attorney General of Belize, n 98 above. 
particular detail in Lord Collins's account of the development of the principle 'and what its nature and limits are'.101 The judgment clarified the ADP in several respects. For instance, it was confirmed that the ADP, '[b]y contrast with the pari passu principle' has no application where the deprivation happens for reasons other than insolvency.102 Most famously, Belmont puts great weight on commercial good faith in deciding whether a given arrangement is in violation of the ADP. ${ }^{103}$ In the words of Lord Collins, the ADP concerns 'intentional or inevitable evasion of the principle that the debtor's property is part of the insolvent estate' and it should be 'applied in a commercially sensitive manner, taking into account the policy of party autonomy and the upholding of proper commercial bargains'. ${ }^{104}$ The eight paragraphs of Lord Collins's opinion elaborating on this aspect of applying the ADP were cited in full by the Court of Appeal in Carlton, which described the extract as 'an authoritative statement of the anti-deprivation principle'. In the same paragraph of the Carlton judgment, it was observed that the Supreme Court's decision rejected the 'flawed asset theory' version of the ADP, as set out by Patten LJ in the Court of Appeal, in favour of a test which considered

each transaction on its merits to see whether the shift in interests complained of could be justified as a genuine and justifiable commercial response to the consequences of insolvency. ${ }^{105}$

In light of all of this, it is perhaps unsurprising that the Court of Appeal in Carlton agreed with the first instance judge on the effects of the disputed section of the derivatives contract in question. Looking at the matter on this 'case specific basis', ${ }^{106}$ the Court of Appeal proceeded to check the purpose of section 2(a)(iii) of the ISDA MA, then, finding its effects were not 'uncommercial', it confirmed there was no breach of the ADP. ${ }^{107}$

The LSE event also considered the limitations of the Belmont decision, as applied in the Carlton appeal. Specifically, it was argued that applying the ADP on a 'case specific basis' to individual transactions, as it was in Carlton, risked creating considerable uncertainty in practice, particularly for those asked to opine on the robustness of a arrangements governed by English law. Further, it was submitted that the discussion of pari passu in the Carlton appeal was a source of confusion. In

\footnotetext{
101 Belmont, n 6 above, [58]-[101].

102 ibid, [80]-[83].

103 ibid, [102]-[106]: the ADP is to be applied in a 'commercially sensitive manner' [106]. Later, it was held to be significant that the arrangement in question 'was a complex commercial transaction entered into in good faith'. [108].

104 ibid, [106].

105 Lomas, Court of Appeal, n 92 above, [86] (discussing the second of four conjoined appeals, which was the appeal from Carlton, n 50 above).

106 ibid, [91].

107 ibid, [92].
} 
this case, LBSF was an insolvent Lehmans entity that had defaulted but was 'in the money' under its derivatives contracts. It therefore sought to establish that section 2(a)(iii) of the ISDA MA gave its counterparty no grounds to refuse to pay. Counsel for LBSF, as an alternative to arguing that section 2(a)(iii) was in violation of the ADP, argued that the section breached the pari passu rule. LBSF was, however, a creditor, and the disputed section 2(a)(iii) of the contract was being used by the debtor counterparty as justification for not making payment in. The pari passu rule deals with the distribution of the insolvent's estate, so its use in this context might have been expected to have been dealt with swiftly by the Court of Appeal. However, the Court stated that '[a]lthough we can see how an attempt by a debtor to resist payment (as in British Eagle) by relying on contractual arrangements which offend against the pari passu rule could be defeated by the application of that rule, the circumstances are likely to be unusual'. ${ }^{108}$ On these facts, there were no such unusual circumstances, and, like the ADP appeal, the pari passu point raised by LBSF was unsuccessful. This part of the judgment was, however, cited as having the potential to cause uncertainty about when the pari passu rule applies.

The second interaction between Lehmans case law and the insolvency regime involved statutory (rather than common law) provisions. In this area, the cases provide useful guidance on how statutory rules may be applied, while shedding light on the strengths and weaknesses of the relevant provisions. One of the examples discussed at the LSE event was the LBIE administrators' application under paragraph 63 of Schedule B1 of the Insolvency Act 1986 for the court's guidance about a proposed Scheme of Arrangement. Schemes of Arrangement are provided for by Part 26 of the Companies Act 2006, 109 and they consist of a binding agreement between a company and its creditors or members (section 895(1) of the Companies Act 2006). The Scheme in question here was proposed by the administrators of LBIE, and it was intended to be between LBIE and 'the persons who are its creditors in relation to Trust Property'. ${ }^{110}$ It was described in the witness statement of one of the LBIE administrators as providing

[...] a system for dealing with all property of, or held in the name of, or otherwise to the order of, LBIE which is subject to trust or proprietary claims, whether comprising monies under the FSA's Client Money Rules ("Client Money") or other monies or assets ("Trust Assets") (together with "Trust Property") in an orderly and efficient manner [...] ${ }^{111}$

The main difficulty presented by this proposal was that the statutory provisions contain no definition of the key term 'creditors', i.e., of the class on whom a Scheme is to be binding once it has been approved by the required $75 \%$

\footnotetext{
108 ibid, [99].

109 As a technical matter, at this stage, the court was being asked to give an order that a creditors' meeting be summoned to vote on the proposed Scheme.

${ }^{110}$ LBIE, n 19 above, [11].

111 Witness Statement of Mr Steven Pearson, cited in ibid, [11].
} 
majority. ${ }^{112}$ This was problematic because the proposed LBIE Scheme involved the holders of beneficial property rights releasing them, while a dissenting minority would be forced to do so unwillingly. The question posed by the administrators' application to court was whether such a group could be described as 'creditors' for the purposes of Part 26 in the first place.

The Court of Appeal and first instance judge both acknowledged that Scheme was the administrators' attempt to tackle the considerable challenges of this complex administration. The Court of Appeal stated, however, that 'we are not concerned on this appeal with fairness or reasonableness of the proposal' ${ }^{\prime 113}$ and, dismissing the administrators' appeal, held that it had no jurisdiction to approve a Scheme which dealt with beneficial owners rather than those with personal claims. In light of the discussion about the flexible application of the law of trusts above, it is interesting to note that, in this context, the Court of Appeal was emphatic about maintaining the distinction between personal and proprietary claims. Indeed, Patten LJ expressly rejected arguments whereby counsel for the administrators sought

to minimise these legal distinctions by treating agreements such as the [prime brokerage agreement] as an overall commercial arrangement which should be looked at in the round for the purposes of Part 26. The commercial nature of these agreements is not in doubt but the trust mechanism has long been regarded as an important safeguard against insolvency and has been imported into commercial contracts for that very reason [...] I do not therefore accept that the trust element in these arrangements ought in some way to be merged into the general contractual framework and treated merely as ancillary when considering the limits of the Scheme jurisdiction or (which is more important) that Parliament ever intended to deal with it in that manner. ${ }^{114}$

In upholding this distinction, the Court of Appeal held that a Scheme envisaged under the Act must mean 'an arrangement between a company and its creditors [...] which deals with their rights inter se as debtor and creditor'. It might include a creditor with rights in the company's own property held as security, but it would exclude a beneficiary with a proprietary claim to trust property. ${ }^{115}$ The Court of Appeal thereby provided a relatively narrow reading of the coverage of Schemes of Arrangement, and rejected the proposal put forward by the administrators of LBIE on this occasion. Outside of the practical ramifications for the LBIE administrators, this decision is significant more broadly, because of the popularity of this statutory process with companies seeking to reach a compromise with members or creditors.

112 s 899, Companies Act 2006.

113 LBIE, n 19 above, [56].

114 ibid, [68].

115 ibid, [65]-[67]. 
Thirdly, in terms of the impact of the Lehmans cases in this area, it was explained at the LSE event that the Lehmans insolvency has directly triggered reform of the UK insolvency regime. Notably, the Investment Bank Special Administration Regulations 2011 ('SAR'), 116 introduced pursuant to section 233 of the Banking Act 2009, were a direct response to problems encountered in the LBIE administration. It was noted that the section 233(3) of the Banking Act 2009 set out five, ambitious and, at least partially, conflicting objectives for the SAR, including, for instance, protecting both proprietary rights and the unsecured estate. The April 2013 interim review of the SAR, published by Peter Bloxham, ${ }^{117}$ was discussed, though his final in-depth report had not been published at the time of the LSE event. The Bloxham review concluded that the SAR have made helpful amendments to the existing legal framework, though found that they have not introduced radical change. Making reference to the LBIE litigation, as well as the three firms which have, to date, been placed in special administration ${ }^{118}$ the review identified areas for improvement. These included the need for a mechanism that facilitates the rapid transfer of customer's positions and limitations to the liabilities faced by administrators. Thus, the SAR were found to have made a contribution to promoting the objectives in the Banking Act, though their effectiveness could still be improved.

\section{CONCLUSION}

There have been over 30 Lehmans decisions handed down by the English courts since the collapse of the group in 2008. The overall objective of this paper has been to highlight the impact of those decisions beyond the administration itself. It has argued that this task requires thinking about the impact of the case law on other users of standard form contracts, on the global financial markets, on English common law and on UK regulation.

Many of those involved in the Lehmans litigation have acknowledged the third party effects of the cases as they have gone along. To take one example, the Court of Appeal in the Scheme of Arrangement application heard from the London Investment Banking Association (LIBA). This organisation put its case particularly bluntly, warning that allowing the administrators' proposed Scheme of Arrangement would have 'unfortunate implications for London as a world financial centre'.119 As discussed above, the judiciary has, in turn, expressly acknowledged the market-wide impact of the Lehmans decisions, most notably,

\footnotetext{
116 SI 2011/245.

117 P Bloxham, Review of the Investment Bank Special Administration Regulations 2011 (HM Treasury: 2013) available https://www.gov.uk/government/uploads/system/uploads/attachment data/file/190983/peter bloxha m review of investment bank sar2011.pdf(last accessed 5 February 2014).

118 MF Global UK Ltd, Worldspreads Ltd and Pritchard Stockbrokers Ltd.

${ }^{119}$ LBIE, n 19 above, [76].
} 
perhaps, in those judgments interpreting the ISDA MA. Famously, this contract was described by Mr Justice Briggs, before interpreting key sections of it in Lomas, as ' $[\ldots]$ probably the most important standard market agreement used in the financial world'. ${ }^{120}$

Submissions by LIBA, ISDA and other interested parties, and the recognition of the broader impact of the cases within judgments, are all highly significant, but there remains a difference between acknowledging third party effects over the course of a particular piece of litigation, and assessing the precedential effects of a set of cases in a systematic way. Scholars of regulation have long seen the benefit of this sort of 'big picture' analysis in helping to understand the long-term effects of financial crises. For example, there is a well-established literature debating the shared characteristics of the waves of regulatory reforms that inevitably follow on from financial crashes. ${ }^{121}$ Though spikes of litigation seem an equally inevitable aspect of the aftermath of crises, scholars of the common law have tended not to undertake this sort of inquiry. As a result, there remains a gap in our understanding of the long-term effects of calamities like the collapse of Lehmans. The LSE workshop was designed to acknowledge the importance of the case law in telling this story. It is hoped that the brief report of this event offered here, focusing on contractual interpretation, the law of trusts and insolvency law, will help to raise awareness of the wholesale effects of the Lehmans case law, and thereby spark a broader debate about the impact of crises by way of the courts.

\footnotetext{
${ }^{120}$ Lomas, n 20 above, [53].

${ }^{121}$ See, e.g., J Coffee 'The political economy of Dodd-Frank: Why financial reform tends to be frustrated and systemic risk perpetuated' in E Ferran et al (eds) The Regulatory Aftermath of the Global Financial Crisis (CUP: 2012), which considers, inter alia, '[w] hy is it that securities and financial reform legislation seems only to be passed after a crash or similar crisis?' 302 .
} 


\section{APPENDIX 1:}

Lehman Brothers insolvency: English judicial decisions, by court and by date, as at 15 November 2013.

\begin{tabular}{|c|c|c|c|c|c|c|}
\hline & $\begin{array}{l}\text { High Court } \\
\text { (Chancery) }\end{array}$ & $\begin{array}{l}\text { High Court } \\
\text { (QBD/ } \\
\text { Commercial) }\end{array}$ & Other & $\begin{array}{l}\text { Court of } \\
\text { Appeal }\end{array}$ & $\begin{array}{l}\text { House of } \\
\text { Lords/ } \\
\text { Supreme } \\
\text { Court }^{122}\end{array}$ & Total \\
\hline 2008 & 2 & & & & & 2 \\
\hline 2009 & 6 & & & 2 & & 8 \\
\hline 2010 & 4 & & 1 (note 2 ) & 1 & & 6 \\
\hline 2011 & 3 & 1 & & 2 & 1 & 7 \\
\hline 2012 & 2 & & 1 (note 3 ) & 1 & 1 & 5 \\
\hline \multirow[t]{2}{*}{2013} & 1 & 1 & & 2 & 1 & 5 \\
\hline & 18 (note 1 ) & 2 & 2 & 8 (note 4 ) & 3 (note 5) & 33 \\
\hline
\end{tabular}

Notes:

1. Of these 18 decisions, 12 were handed down by Mr Justice Briggs (as he then was).

2. Determinations Panel of the Pensions Regulator.

3. Upper Tribunal Tax and Chancery Chamber.

4. Re Lehman Brothers International (Europe) [2009] EWCA Civ 1161; Belmont Park Investments Pty Ltd v BNY Corporate Trustee Services Ltd [2009] EWCA Civ 1160; Re Lehman Brothers International (Europe) [2010] EWCA Civ 917; Re Lebman Brothers International (Europe) [2011] EWCA Civ 1544; Bloom v Pensions Regulator [2011] EWCA Civ 1124; Lomas v JFB Firth Rixson Inc [2012] EWCA Civ 419; Lehman Brothers International (Europe) v Lehman Brothers Finance SA [2013] EWCA Civ 188; Trustees of Lehman Brothers Pension Scheme v Pensions Regulator [2013] EWCA Civ 751.

5. $\quad$ Belmont Park Investments Pty Ltd v BNY Corporate Trustee Services Ltd [2011] UKSC 38; Re Lehman Brothers International (Europe) [2012] UKSC 6; Bloom v Pensions Regulator [2013] UKSC 52.

\footnotetext{
122 The Supreme Court replaced the House of Lords in October 2009.
} 


\section{APPENDIX 2:}

Lehman Brothers insolvency: Selected decisions by the English courts, as at 15 November 2013, by subject matter.

\section{Client assets: Urgent applications}

1.1 Application for return of client assets, one week after administration: $R A B$ Capital Plc v Lehman Brothers International (Europe) [2008] EWHC 2335(Ch).

1.2 Application by four anonymous clients, seeking information about assets: $\mathrm{Re}$ Lehman Brothers International (Europe) (In Administration) [2008] EWHC 2869 (Ch).

\section{Administrators' Scheme of Arrangement}

2.1 Re Lehman Brothers International (Europe) [2009] EWCA Civ 1161; appeal from [2009] EWHC 2141 (Ch).

\section{Derivatives}

3.1 Effect of section 2(a)(iii) ISDA MA: Lomas v JFB Firth Rixson Inc [2012] EWCA Civ 419, appeal from Lomas [2010] EWHC 3372 (Ch) and Lehman Brothers Special Financing Inc v Carlton Communications Ltd [2011] EWHC 718 (Ch), plus two forward freight agreement cases.

3.2 Effect of side letter on close-out netting under section 6 ISDA MA 2002: Lehman Brothers International (Europe) v Lehman Brothers Finance SA [2012] EWHC 1072 (Ch), successfully appealed in [2013] EWCA Civ 188 (the 'Back to Back Transactions' litigation).

3.3 Allowing set-off between letter of credit and early termination amounts due under ISDA MA: Lehman Brothers Commodity Services Inc v Credit Agricole Corporate and Investment Bank (formerly Calyon) [2011] EWHC 1390 (Comm).

\section{Client money: CASS rules}

4.1 How client money rules (CASS7) applied in practice, when a statutory trust arises and how to share pooled assets: Re Lehman Brothers International (Europe) [2012] UKSC 6, appeal from [2010] EWCA Civ 917 and [2009] EWHC 3228 (Ch). (NB, [2010] EWHC 47 was handed down a few weeks after [2009] EWHC 3228, and is a short, supplementary judgment). 


\section{Client assets: Rights on insolvency}

5.1 Prime brokerage client securities 'leaking' into cash as group went into administration: Re Lehman Brothers International (Europe) [2009] EWHC 2545 (Ch). (the 'MCF' litigation)

5.2 Beneficial ownership of securities subject to intra-group Rascals process: Re Lehman Brothers International (Europe) [2011] EWCA Civ 1544, appeal from [2010] EWHC 2914. (the 'Rascals' litigation).

5.3 Re Lehman Brothers International (Europe) [2012] EWHC 2997 (Ch). Application by administrators for directions in relation to security documents. Questions of interpretation about what sort of security was created, and, once characterised, whether it fell within FCAR 2003. (the 'Extended Liens' application). Related disclosure application: Re Lehman Brothers International (Europe) [2011] EWHC 2022 (Ch).

\section{Structured finance}

6.1 Validity of 'flip' provision, in light of the anti-deprivation rule: Belmont Park Investments Pty Ltd v BNY Corporate Trustee Services Ltd [2011] UKSC 38, appeal from Belmont Park Investments Pty Ltd v BNY Corporate Trustee Services Ltd [2009] EWCA Civ 1160 and from Perpetual Trustee Co Ltd v BNY Corporate Trustee Services Ltd [2009] EWHC 1912 (Ch).

6.2 Related hearing on jurisdiction, considering parallel SDNY proceedings: Perpetual Trustee Co Ltd v BNY Corporate Trustee Services Ltd [2009] EWHC 2953 (Ch).

6.3 Meaning and effect of close-out provisions in put options used in two structured finance deals, both governed by 1992 ISDA MA: Anthracite Rated Investments (Jersey) Ltd v Lehman Brothers Finance S A [2011] EWHC 1822 (Ch).

\section{Other}

7.1 Pensions: Re Lehman Brothers Pension Scheme [2010] Pens. L.R. 445; Bloom v Pensions Regulator [2010] EWHC 3010 (Ch); appealed in [2011] EWCA Civ 1124 and [2013] UKSC 52. Trustees of Lehman Brothers Pension Scheme v Pensions Regulator [2012] Pens LR 435, appealed in [2013] EWCA Civ 751.

7.2 Jurisdiction: Lehman Brothers Bankhaus AG I. INS v CMA CGM [2013] EWHC 171 (Comm). Articles 27 and 28 of EC Regulation 44/2001 discussed. 